\title{
Analysis of the implementation of Hearing Conservation Programs
}

\author{
Alcineide da Silva Pimenta ${ }^{1}$ \\ https://orcid.org/0000-0001-9439-9902 \\ Vanessa Maria da Silva1 \\ https://orcid.org/0000-0001-7257-102X \\ Cleide Fernandes Teixeira ${ }^{2}$ \\ https://orcid.org/0000-0001-9869-4431 \\ Cynthia Maria Barboza do Nascimento 2 \\ https://orcid.org/0000-0001-9197-2136 \\ Lílian Ferreira Muniz ${ }^{1}$ \\ https://orcid.org/0000-0002-0450-4148 \\ Adalva Virgínia Couto Lopes ${ }^{1}$ \\ https://orcid.org/0000-0001-7873-7764 \\ Suzy Maria Gomes ${ }^{2}$ \\ https://orcid.org/0000-0001-6478-843X \\ Maria Luiza Lopes Timóteo de Lima1 \\ https://orcid.org/0000-0001-8600-0017
}

Universidade Federal de Pernambuco UFPE, Programa de Pós-graduação em Saúde da Comunicação Humana, Recife, Pernambuco, Brasil.

2 Universidade Federal de Pernambuco UFPE, Departamento de Fonoaudiologia, Recife, Pernambuco, Brasil.

Research support source: Coordenação de Aperfeiçoamento de Pessoal de Nível Superior - CAPES.

Conflict of interests: Nonexistent

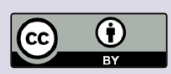

Received on: July 4, 2020

Accepted on: October 20, 2020

Corresponding address:

Alcineide da Silva Pimenta.

Rua Professor Artur de Sá, s/n -

Cidade Universitária

CEP: 50670-420 - Recife, Pernambuco,

Brasil

E-mail: alcineide15@hotmail.com

\section{ABSTRACT}

Purpose: to assess the implementation of hearing conservation programs in two large companies.

Methods: an evaluative research that analyzed a type $1 \mathrm{~b}$ implementation. The study was conducted in three stages, namely: establishing the company's degree of implementation, analyzing the companies' policies and structures, and lastly, analyzing the influence of the companies' policies and structures on their degree of implementation. The following analyses were conducted to collect data: interviews, document analysis, and observation.

Results: the hearing conservation program in Company A was classified as implemented $(91.1 \%)$, while in Company B, it was partially implemented $(62.7 \%)$. The context in Company A was favorable to implementing the program, whereas in Company $\mathrm{B}$, the context was considered unfavorable, due to disadvantageous categories. Also, the characteristics of the implementation context influenced the placement of the program either positively or negatively.

Conclusion: there were satisfactory results regarding the implementation of the hearing conservation program in both companies assessed.

Keywords: Health Assessment; Noise-Induced Hearing Loss; Program Evaluation 


\section{INTRODUCTION}

Noise-induced hearing loss (NIHL) is still one of the most prevalent occupational diseases worldwide. It affects workers in a wide range of businesses and industries, as a result of continuous or intermittent exposure to high-intensity noise, slowly developing throughout many years ${ }^{1,2}$.

In Brazil, every company is obligated to implement an Environmental Risk Prevention Program (PPRA, as abbreviated in Portuguese). If the program detects a high sound pressure level as a risk agent, the company must organize a hearing conservation program (HCP), as established by the regulatory norm no. $9^{3}$.

The HCP is a set of actions aiming to prevent or stabilize occupational hearing losses through continuous improvement processes. Based on the knowledge of a multidisciplinary team, it is developed with planned and coordinated activities involving the various sectors of the company ${ }^{3}$.

Among the HCP actions, the following are highlighted: measures to monitor and control the environmental noise at the workplace, selection and provision of hearing protection devices, audiometric monitoring, workers' training and instruction, updated records, and program assessment ${ }^{4}$.

For the HCP to be feasible and effective, all the stages must be properly carried out and coordinated. Also, it must count on the active participation of health professionals, safety personnel, managers, human resources, and especially the workers ${ }^{5}$.

Considering the complex and broad components of the HCP activities, assessing it is an emerging need, taking into account each company's context and structure particularities.

The assessment via implementation analysis is a tool that helps understand how the HCP is being put into effect in the companies. It provides information on the dynamics of the program as actually implemented, also considering the influence of contextual factors that either facilitates or hinders their implementation. Such an assessment offers the basis to plan and develop the program's activities ${ }^{6}$.

It is important to emphasize that the results of an assessment can help in decision-making regarding the continuity, modification, or interruption of the actions being developed, organization of the work, and the practice of the professionals involved in the HCP.

Few papers are found in the literature approaching the assessment of HCP in companies. This may be due to difficulties found when implementing it or the little experience in assessing programs on the part of those responsible for the HCP5.

The study on HCP implementation analysis is part of the effort made by speech-language-hearing and public health researchers to develop evaluative pieces of research. Their purpose is to list the multiple aspects involved in the processes of implementing health policies, programs, and services ${ }^{7}$.

Hence, this study aimed to assess the implementation of the HCP in two large companies in the state of Pernambuco, Brazil.

\section{METHODS}

This evaluative research, conducted from March to November 2019, analyzed type $1 \mathrm{~b}$ implementations. Its objective was to understand the variations observed in the degree of implementation and its context ${ }^{6}$. The study was approved by the Research Ethics Committee of the Universidade Federal de Pernambuco, Brazil, under evaluation report number 3.197.976.

The strategy used was the study of multiple cases at the same level of analysis ${ }^{8}$ to investigate complex social phenomena and preserve holistic and significant characteristics of real-life events.

The selected cases were two large companies, one from the public sector (Company $A$ ) and the other from the private sector (Company $B$ ), both located in the Recife Metropolitan Area (RMA), in Pernambuco, Brazil. The cases were chosen based on the following inclusion criteria: having an HCP for at least five years and being a large company ${ }^{9}$ (more than 100 employees). The exclusion criterion was the company's not having an occupational medicine department responsible for the HCP activities.

The study was conducted in three stages, namely: (1) establishing the company's degree of implementation; (2) studying the companies' policies and structures; and (3) analyzing the influence of the companies' policies and structures on their degree of implementation. 


\section{Stage 1: Establishing the company's degree of implementation}

The HCP actions logical model $(\mathrm{LM})^{10}$ and the HCP analysis and judgment matrix (AJM), developed and validated by specialists ${ }^{11}$, were used to establish the degree of implementation.

In this perspective, it is essential to consider the HCP basic components in order to establish the degree of implementation - i.e., it involves a phase with explanations of the resources employed and their organization (structure) and the services or goods produced (process). The LM furnishes a visual organization of how the program works and what the causal relationship between its elements is ${ }^{6}$.

The AJM presents criteria, structure and process indicators, verification parameters, and the score expected for each indicator, thus providing a quantified value for the HCP. The AJM items were used as a basis to construct this study's collection instruments. To obtain the degree of implementation (DI), three sources of evidence were used: interviews, document surveys, and direct observation.

Initially, interviews were conducted with a structured questionnaire based on the indicators listed in the AJM. The goal of the questionnaire was to gather information, such as data about the company (business, number of employees, existing health programs, and so forth), and data on the HCP structure and processes (actions) in the companies. In this stage, the key contacts for information were the occupational physician (Company A) and the occupational nurse (Company B). Both were chosen for being directly related to the hearing health activities in these companies.

The direct observation was carried out in both companies by the researcher to verify the human resources and material employed in the HCP, as informed by the administrators. The document survey aimed to verify the record of the actions developed in the HCP, complement them, and compare them with the data obtained in the interviews.

The documents made available by the administrators and assessed by the researcher were the reports on the Occupational Health Medical Control Program (PCMSO, as abbreviated in Portuguese), Environmental Risk Prevention Program (PPRA), and HCP, copy of the audiometry, PPE approval certificate, clinical-occupational anamnesis form, accidents at work notification form, and occupational health certificate.

All the said stages were carried out in person at the companies. The researcher was welcomed to the administrators' office, where they were asked to answer all the questions and were informed that the interviews would be recorded.

Based on the data obtained from the sources of evidence, each company's DI was established, using a system of scores with a cutoff according to criteria that referred to the structure and process indicators listed in the AJM.

When the indicator reached the stipulated parameter, the full score was given; when it did not reach it, no score was given. In case the key contact did not know the answer to the question, or the activities related to that indicator, a score was not given, either. When some activity did not apply to the company's situation, the indicator was considered not applicable (NA). The score referring to this indicator was subtracted from the expected score and the final DI score.

Given the importance and complexity of the processes implemented in the HCP, the weight of these components' scores on the analysis was six, whereas that of the structure components was four. Since the number of criteria varied between the components, the score was presented in percentages for the comparison.

Hence, the score was calculated as percentages in relation to the expected score for each indicator $100 \%$ was the highest expected percentage, using the formula presented below in Figure 1. 
GI Total $=\left(\frac{\left(4 \sum E^{t}+6 \sum P^{I}\right) / 10}{\left(4 \sum E^{2}+6 \sum P^{2}\right) / 10}\right) * 100$

Captions: $\Sigma \mathrm{E}^{1}=$ Sum of the scores obtained in the indicators that made up the "Structure" dimension; $\Sigma \mathrm{P}^{1}=$ Sum of the scores obtained in the indicators that made up the "Process" dimension; $\Sigma \mathrm{E}^{2}=$ Sum of the scores expected in the indicators that made up the "Structure" dimension; $\Sigma \mathrm{P}^{2}=$ Sum of the scores expected in the indicators that made up the "Process" dimension.

Figure 1. Formula to calculate the degree of implementation of the hearing conservation program

To judge the company's DI value, four cutoff scores were considered, as proposed by Samico ${ }^{12}:<25.0 \%$ - not implemented; $25.1 \%$ to $50.0 \%$ - incipient implementation; $50.1 \%$ to $75.0 \%$ - partially implemented; $>75.1 \%$ - implemented.

\section{Stage 2: studying the companies' policies and structures}

The parameters used to judge the context in which the HCP was implemented in the companies were based on the Policy and Contingency Model, inspired on the policy and structure models, and classified as "favorable" or "unfavorable" to the implementation of the $\mathrm{HCP}^{13}$.

This model is guided by some questions, which were assessed as either favorable or not, based on the criteria considered and listed in each category of the analysis. The reference for the criteria established for contextual analysis is the actions considered favorable to the implementation of the HCP.
These data were obtained with a semi-structured interview with these companies' PCMSO administrators (both were occupational physicians) to analyze what strategies are offered to fully perform the program. The interviews were voice-recorded for future transcription and analysis. They were centered on the investigated theme cores, originated on the analysis categories of the policy and structure context developed for other programs, and adapted to the $\mathrm{HCP}^{14}$.

The main theme cores investigated by category were: a) Formalization of the sector responsible for planning the PCMSO and/or HCP; b) Profile of the HCP administrator; c) Attention given to innovation; d) Size; e) Centralization; f) Formalization; g) HCP planning and assessment; h) HCP implementation investments; i) Familiarity with the HCP; j) Familiarity with and follow-up on the financial resources available for the HCP actions; and k) Priority given to implementing the $\mathrm{HCP}$ in the company.

\section{Stage 3: Analyzing the influence of the companies' policies and structures on their degree of implementation}

To analyze the influence the context had on the DI of the HCP, the pieces of evidence found in information gathered from the different data collection methods were mutually crossed.

\section{RESULTS}

Figures 2 and 3 detail the process and structure indicators used to establish the DI of the HCP in both companies, and the maximum expected and achieved values in each of the components. 


\begin{tabular}{|c|c|c|c|c|c|}
\hline \multirow{2}{*}{ COMPONENT } & \multirow{2}{*}{ DIMENSION } & \multirow{2}{*}{ INDICATOR } & \multirow{2}{*}{$\begin{array}{l}\text { EXPECTED } \\
\text { SCORE }\end{array}$} & \multicolumn{2}{|c|}{ OBTAINED SCORE } \\
\hline & & & & COMPANY A & COMPANY B \\
\hline \multirow{26}{*}{ 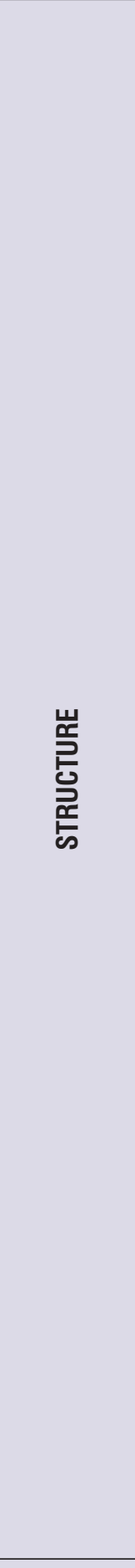 } & \multirow{26}{*}{ 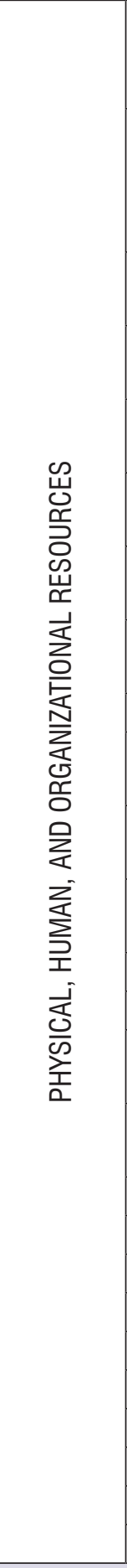 } & $\begin{array}{l}\text { 1. Existence of a person or position in the company responsible for } \\
\text { ensuring administrative resources and measures to carry out the } \\
\text { hearing conservation program. }\end{array}$ & 3.0 & 3.0 & 3.0 \\
\hline & & $\begin{array}{l}\text { 2. Existence of a specialized safety engineering and occupational } \\
\text { medicine service, either with a person or team, that at the } \\
\text { employer's will are apt to develop projects and engineering } \\
\text { measures. }\end{array}$ & 2.0 & 2.0 & 2.0 \\
\hline & & $\begin{array}{l}\text { 3. Existence of an occupational physician responsible for the } \\
\text { occupational health medical control program. }\end{array}$ & 3.0 & 3.0 & 3.0 \\
\hline & & $\begin{array}{l}\text { 4. Existence of a professional or team of professionals technically } \\
\text { skilled to develop the hearing conservation program (HCP). }\end{array}$ & 3.0 & 3.0 & 3.0 \\
\hline & & $\begin{array}{l}\text { 5. Existence of a specialized professional to perform the } \\
\text { audiological examinations. }\end{array}$ & 2.0 & 2.0 & 2.0 \\
\hline & & $\begin{array}{l}\text { 6. Professional training completed for them to perform audiological } \\
\text { examinations. }\end{array}$ & 3.0 & 3.0 & 3.0 \\
\hline & & $\begin{array}{l}\text { 7. Existence of qualified professionals to carry out educational } \\
\text { actions. }\end{array}$ & 1.0 & 1.0 & 1.0 \\
\hline & & $\begin{array}{l}\text { 8. Proof that the audiometric examination is conducted in the } \\
\text { audiometric booth(s) or acoustically treated environment(s). }\end{array}$ & 3.0 & 3.0 & 3.0 \\
\hline & & 9. Existence of a risk analysis report. & 3.0 & 3.0 & 0.0 \\
\hline & & $\begin{array}{l}\text { 10. Existence of a report on the planning of the Environmental Risk } \\
\text { Prevention Program (PPRA). }\end{array}$ & 3.0 & 3.0 & 3.0 \\
\hline & & $\begin{array}{l}\text { 11. Existence of a report on the occupational health medical control } \\
\text { program (PCMSO). }\end{array}$ & 3.0 & 3.0 & 3.0 \\
\hline & & $\begin{array}{l}\text { 12. Existence of a report on personal protective equipment (PPE) } \\
\text { attenuation trials. }\end{array}$ & 3.0 & 3.0 & 0.0 \\
\hline & & 13. Existence of a report on HCP implementation. & 3.0 & 3.0 & 0.0 \\
\hline & & 14. Existence of adequate PPE to each activity's risk. & 1.0 & 1.0 & 1.0 \\
\hline & & $\begin{array}{l}\text { 15. Existence of an approval certificate of the PPE used by the } \\
\text { employees. }\end{array}$ & 2.0 & 2.0 & 2.0 \\
\hline & & $\begin{array}{l}\text { 16. Proof that the audiometric examination is conducted in duly } \\
\text { calibrated measuring equipment. }\end{array}$ & 3.0 & 3.0 & 3.0 \\
\hline & & 17. Existence of audiometric examination forms. & 1.0 & 1.0 & 1.0 \\
\hline & & 18. Existence of clinical-occupational anamnesis. & 1.0 & 1.0 & 1.0 \\
\hline & & 19. Existence of accident at work notification forms. & 1.0 & 1.0 & 1.0 \\
\hline & & 20. Existence of individual clinical record. & 2.0 & 2.0 & 2.0 \\
\hline & & 21. Existence of proof of delivery of audiometric examination. & 1.0 & 1.0 & 1.0 \\
\hline & & 22. Existence of proof of delivery of hearing protection device. & 1.0 & 1.0 & 1.0 \\
\hline & & 23. Existence of minutes. & 1.0 & 1.0 & 1.0 \\
\hline & & 24. Existence of educational material. & 2.0 & 2.0 & 0.0 \\
\hline & & 25. Existence of informational material. & 2.0 & 2.0 & 2.0 \\
\hline & & 26. Instrument to measure the degree of implementation of the HCP. & 2.0 & 0.0 & 0.0 \\
\hline & & TOTAL VALUE & 56.0 & 53.0 & 39.0 \\
\hline
\end{tabular}

Source: Authors of the paper.

Captions: HCP - Hearing conservation program; PPE - Personal protective equipment; PPRA - Environmental Risk Prevention Program; PCMSO - Occupational health medical control program.

Figure 2. Structure indicators and expected and obtained scores in each company 


\begin{tabular}{|c|c|c|c|c|c|}
\hline \multirow{2}{*}{ COMPONENT } & \multirow{2}{*}{ DIMENSION } & \multirow{2}{*}{ INDICATOR } & \multirow{2}{*}{$\begin{array}{l}\text { EXPECTED } \\
\text { SCORE }\end{array}$} & \multicolumn{2}{|c|}{ OBTAINED SCORE } \\
\hline & & & & COMPANY A & COMPANY B \\
\hline \multirow{36}{*}{$\begin{array}{l}\text { 岂 } \\
\text { 岕 } \\
\text { 。्̊ }\end{array}$} & \multirow{7}{*}{ 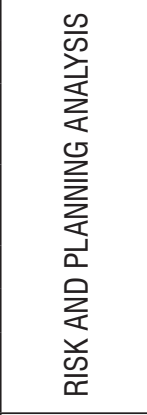 } & 27. Preliminary noise exposure assessment. & 3.0 & 3.0 & 0.0 \\
\hline & & 28. Quantitative noise exposure assessment. & 3.0 & 3.0 & 0.0 \\
\hline & & $\begin{array}{l}\text { 29. Identification of homogeneous groups that have the same exposure } \\
\text { characteristics. }\end{array}$ & 2.0 & 2.0 & 2.0 \\
\hline & & $\begin{array}{l}\text { 30. Analysis of the (co)existence of other risk agents (chemical, physical, } \\
\text { and biological). }\end{array}$ & 2.0 & 2.0 & 0.0 \\
\hline & & 31. Establishing HCP responsibilities, goals, and priorities. & 3.0 & 3.0 & 0.0 \\
\hline & & 32. Establishing action strategies and methodologies. & 3.0 & 3.0 & 0.0 \\
\hline & & $\begin{array}{l}\text { 33. Presentation and discussion of the annual planning along with sectors } \\
\text { involved with the HCP. }\end{array}$ & 2.0 & 2.0 & 0.0 \\
\hline & \multirow{6}{*}{ 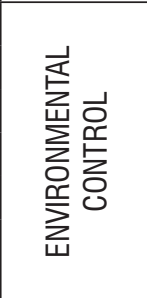 } & 34. Participation in the implementation of engineering measures. & 2.0 & 2.0 & 2.0 \\
\hline & & 35. Participation in the implementation of administrative measures. & 2.0 & 2.0 & 2.0 \\
\hline & & 36. Selection of adequate PPE. & 2.0 & 2.0 & 2.0 \\
\hline & & 37. Provision and replacement of PPE to the employees. & 2.0 & 2.0 & 2.0 \\
\hline & & 38. Inspecting the use of PPE. & 2.0 & 2.0 & 2.0 \\
\hline & & $\begin{array}{l}\text { 39. Definition of the employees who must be paid hazard pay or special } \\
\text { retirement due to noise exposure. }\end{array}$ & 2.0 & NSA & NSA \\
\hline & \multirow{19}{*}{ 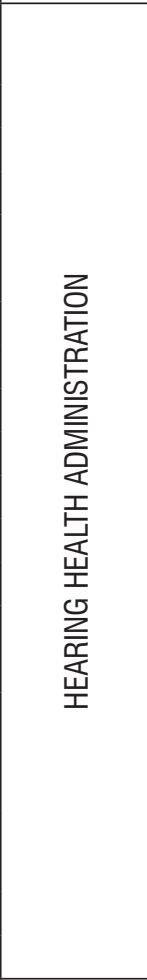 } & $\begin{array}{l}\text { 40. Warranty of the verification procedures and periodic control of the } \\
\text { audiometer proper functioning. }\end{array}$ & 3.0 & 3.0 & 3.0 \\
\hline & & 41. Carrying out occupational anamnesis. & 2.0 & 2.0 & 2.0 \\
\hline & & 42. Performing ear inspection. & 2.0 & 2.0 & 2.0 \\
\hline & & 43. Performing pre-employment audiometric examination. & 3.0 & 3.0 & 3.0 \\
\hline & & 44. Establishing every employee's initial and/or reference audiometry. & 3.0 & 3.0 & 3.0 \\
\hline & & 45. Performing sequential audiometric examinations. & 3.0 & 3.0 & 3.0 \\
\hline & & 46. Performing post-employment audiometric examinations. & 3.0 & 3.0 & 3.0 \\
\hline & & 47. Performing speech audiometry. & 2.0 & 0.0 & 0.0 \\
\hline & & 48. Performing complementary audiological examinations. & 2.0 & 2.0 & 2.0 \\
\hline & & 49. Referring for specialized assessment. & 2.0 & 2.0 & 2.0 \\
\hline & & 50. Establishing differential diagnosis criteria. & 2.0 & 2.0 & 0.0 \\
\hline & & 51. Analysis of the evolution and definition of the evolutive diagnosis. & 3.0 & 3.0 & 3.0 \\
\hline & & 52. Records of the results of the audiological diagnosis administration. & 2.0 & 2.0 & 2.0 \\
\hline & & 53. Notifying accidents at work. & 3.0 & 3.0 & 3.0 \\
\hline & & 54. Records administration. & 2.0 & 2.0 & 2.0 \\
\hline & & $\begin{array}{l}\text { 55. Carrying out training programs, courses, debates, organizing } \\
\text { commissions, participating in events, and other appropriate forms involving } \\
\text { the effects on health caused by exposure to high sound pressure levels. }\end{array}$ & 3.0 & 3.0 & 0.0 \\
\hline & & $\begin{array}{l}\text { 56. Training the employees regarding the implementation of group and } \\
\text { individual measures. }\end{array}$ & 3.0 & 3.0 & 3.0 \\
\hline & & 57. Making available copies of the examinations and medical certificates. & 2.0 & 2.0 & 2.0 \\
\hline & & 58. Listening to the employees' suggestions. & 2.0 & 2.0 & 2.0 \\
\hline & \multirow{4}{*}{ 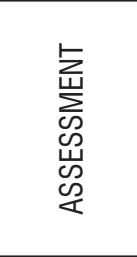 } & $\begin{array}{l}\text { 59. Performing quantitative analysis of prevalence and incidence of the } \\
\text { results of audiological examinations. }\end{array}$ & 3.0 & 3.0 & 0.0 \\
\hline & & 60. Assessing the satisfaction level of the employees. & 2.0 & 2.0 & 0.0 \\
\hline & & 61. Measuring the degree of implementation of the HCP through auditing. & 3.0 & 0.0 & 0.0 \\
\hline & & $\begin{array}{l}\text { 62. Analysis of the contextual factors that can influence HCP } \\
\text { implementation. }\end{array}$ & 2.0 & 0.0 & 0.0 \\
\hline & & TOTAL VALUE & 85.0 & 78.0 & 52.0 \\
\hline
\end{tabular}

Source: Authors of the paper.

Captions: HCP - Hearing conservation program; PPE - Personal protective equipment; NA - Not applicable.

Figure 3. Process indicators and expected and obtained scores in each company 
Table 1 shows the summary of the expected and achieved values per component, and the DI of the HCP. It is noticed that Company A achieved better scores than Company B, as the HCP implementation in Company A was classified as implemented (91.1\%), whereas in Company B it was classified as partially implemented (62.7\%).

Table 1. Distribution of the expected and obtained scores per component and degree of implementation of the hearing conservation program in each company

\begin{tabular}{|c|c|c|c|c|c|}
\hline \multirow{2}{*}{ COMPONENT } & \multirow{2}{*}{ EXPECTED SCORE } & \multicolumn{2}{|c|}{ OBTAINED SCORE } & \multicolumn{2}{|c|}{ DEGREE OF IMPLEMENTATION (\%) } \\
\hline & & COMPANY A & COMPANY B & COMPANY A & COMPANY B \\
\hline STRUCTURE & 56.0 & 53.0 & 39.0 & $91.1 \%=$ & $62.7 \%=$ Partially \\
\hline PROCESS & 87.0 & 78.04 & 52.0 & Implemented & implemented \\
\hline
\end{tabular}

Source: Authors of the paper

The dimension with the best scores among those assessed (Table 2) was "hearing health administration" in both companies. "Assessment", on the other hand, obtained the lowest scores in both companies
- Company B did not score in any of the indicators, followed by "Risk Analysis and Planning", in which it scored in only one indicator.

Table 2. Distribution of the expected and obtained scores per dimensions

\begin{tabular}{ccccc}
\hline \multirow{2}{*}{ COMPONENT } & \multirow{2}{*}{ DIMENSION } & \multirow{2}{*}{ EXPECTED SCORE } & \multicolumn{2}{c}{ OBTAINED SCORE } \\
\cline { 4 - 5 } & PHYSICAL, HUMAN, AND & \multirow{2}{*}{ COMPANY A } & COMPANY B \\
\hline \multirow{3}{*}{ STRUCTURE } & ORGANIZATIONAL RESOURCES & 56.0 & 53.0 & 39.0 \\
& RISK AND PLANNING ANALYSIS & 18.0 & 18.0 & 2.0 \\
& ENVIRONMENTAL CONTROL & 10.0 & 10.0 & 10.0 \\
& HEARING HEALTH ADMINISTRATION & 47.0 & 45.0 & 40.0 \\
& ASSESSMENT & 10.0 & 5.0 & 0.0 \\
\hline
\end{tabular}

Source: Authors of the paper

Regarding the context in which the implementation takes place in the companies, Figures 4 and 5 present the analysis categories, analysis parameters, and the classification of each company's context. The evidence described was gathered in the interviews, document surveys, and direct observation.

The results of the analysis revealed that Company A's implementation context was favorable, as most of the analysis categories were presented as favorable to implementing the HCP. In contrast, Company B's was unfavorable, as most of the analysis categories were presented as disadvantageous to it.

In both companies, the structural context proved to be less favorable to the HCP implementation, with fewer favorable categories than the policy context. The "Attention given to innovation" and "Centralization" were the ones that were considered unfavorable in both companies. 


\begin{tabular}{|c|c|c|c|c|c|}
\hline \multirow{2}{*}{$\begin{array}{l}\text { Research } \\
\text { question }\end{array}$} & \multirow{2}{*}{ Variable } & \multirow{2}{*}{ Category } & \multirow{2}{*}{ Analysis parameters } & \multicolumn{2}{|c|}{ Context evidence and classification } \\
\hline & & & & Company A & \begin{tabular}{|l} 
Company B \\
\end{tabular} \\
\hline \multirow{11}{*}{$\begin{array}{l}\text { Do the } \\
\text { characteristics } \\
\text { of the } \\
\text { administrators, } \\
\text { environment, } \\
\text { and } \\
\text { organization } \\
\text { favor the } \\
\text { implementation } \\
\text { of the } \\
\text { intervention? }\end{array}$} & $\begin{array}{l}\text { Organizational } \\
\text { attributes }\end{array}$ & $\begin{array}{l}\text { Formalization } \\
\text { of the } \\
\text { responsible } \\
\text { sector }\end{array}$ & $\begin{array}{l}\text { There is a sector responsible } \\
\text { for the functioning and } \\
\text { planning of the Occupational } \\
\text { Health Medical Control } \\
\text { Program and/or Hearing } \\
\text { Conservation Program. }\end{array}$ & $\begin{array}{l}\text { There is an occupational health sector } \\
\text { in the company } \\
\text { Source: Direct observation }+ \text { interview } \\
\text { with the administrator } \\
\text { Context favorable to the } \\
\text { implementation }\end{array}$ & $\begin{array}{l}\text { There is an occupational health sector } \\
\text { in the company } \\
\text { Source: Direct observation }+ \text { interview } \\
\text { with the administrator } \\
\text { Context favorable to the } \\
\text { implementation }\end{array}$ \\
\hline & \multirow{3}{*}{$\begin{array}{l}\text { Administrators' } \\
\text { attributes }\end{array}$} & $\begin{array}{l}\text { Profile of } \\
\text { the HCP } \\
\text { administrator }\end{array}$ & $\begin{array}{l}\text { Has a higher education degree; } \\
\text { is specialized in occupational } \\
\text { health or related areas; has } \\
\text { previous experience in the } \\
\text { field of Occupational Health } \\
\text { or Hearing Conservation } \\
\text { Program. }\end{array}$ & $\begin{array}{c}\text { Medical school degree and } \\
\text { specialization in Occupational Health } \\
\text { and Family Health } \\
\text { Source: Interview with the administrator } \\
\text { Context favorable to the } \\
\text { implementation }\end{array}$ & $\begin{array}{l}\text { Medical school degree and } \\
\text { specialization in Occupational Health } \\
\text { Source: Interview with the administrator } \\
\text { Context favorable to the } \\
\text { implementation }\end{array}$ \\
\hline & & \multirow[t]{2}{*}{$\begin{array}{l}\text { Attention } \\
\text { given to } \\
\text { innovation }\end{array}$} & $\begin{array}{l}\text { Seeks to bring and/or support } \\
\text { new HCP actions. }\end{array}$ & $\begin{array}{l}\text { Improvement courses; reported the } \\
\text { need and desire to improve the group } \\
\text { protective equipment. } \\
\text { Source: Interview with the administrator } \\
\text { Context favorable to the } \\
\text { implementation }\end{array}$ & $\begin{array}{l}\text { Improvement courses. } \\
\text { Source: Interview with the administrator } \\
\text { Context favorable to the } \\
\text { implementation }\end{array}$ \\
\hline & & & $\begin{array}{l}\text { Seeks partnerships with } \\
\text { other networks to develop } \\
\text { occupational hearing health } \\
\text { actions. }\end{array}$ & $\begin{array}{l}\text { No evidence was found. } \\
\text { Context unfavorable to implementation }\end{array}$ & $\begin{array}{l}\text { No evidence was found. } \\
\text { Context unfavorable to implementation }\end{array}$ \\
\hline & \multirow{7}{*}{$\begin{array}{l}\text { Environmental } \\
\text { attributes }\end{array}$} & \multirow{4}{*}{ Centralization } & $\begin{array}{l}\text { The number of professionals } \\
\text { involved in carrying out } \\
\text { the HCP is proportional to } \\
\text { the demand of employees } \\
\text { included in the program's } \\
\text { actions } \\
\end{array}$ & $\begin{array}{l}\text { Number of professionals proportional to } \\
\text { the demand } \\
\text { Source: Interview with the administrator } \\
\text { Context favorable to the } \\
\text { implementation }\end{array}$ & $\begin{array}{l}\text { Number of professionals disproportional } \\
\text { to the demand } \\
\text { Source: Interview with the administrator } \\
\text { Context unfavorable to implementation }\end{array}$ \\
\hline & & & $\begin{array}{l}\text { Fully carries out the HCP } \\
\text { actions or needs support from } \\
\text { other third-party company(ies) }\end{array}$ & $\begin{array}{l}\text { Does not fully carry out the HCP } \\
\text { actions, needs support from third-party } \\
\text { companies. There are coordination } \\
\text { and communication between the } \\
\text { program administrator and the providing } \\
\text { company. } \\
\text { Source: Interview with the administrator } \\
\text { + document analysis } \\
\text { Context favorable to the } \\
\text { implementation }\end{array}$ & $\begin{array}{l}\text { Does not fully carry out the HCP } \\
\text { actions, needs support from third- } \\
\text { party companies. There is neither } \\
\text { coordination nor communication } \\
\text { between the program administrator and } \\
\text { the providing company. } \\
\text { Source: Interview with the administrator } \\
\text { Context unfavorable to implementation }\end{array}$ \\
\hline & & & $\begin{array}{l}\text { Decision-making and planning } \\
\text { regarding HCP actions involve } \\
\text { all the sectors with a direct or } \\
\text { indirect relationship with the } \\
\text { program. }\end{array}$ & $\begin{array}{c}\text { The decisions are made by those } \\
\text { involved in the HCP: Occupational } \\
\text { Health and Safety sectors. } \\
\text { Source: Interview with the administrator } \\
\text { Context favorable to the } \\
\text { implementation }\end{array}$ & $\begin{array}{l}\text { Decision-making depends on the } \\
\text { Human Resources department, to } \\
\text { which those involved in the program are } \\
\text { subordinated. } \\
\text { Source: Interview with the administrator } \\
\text { Context unfavorable to implementation }\end{array}$ \\
\hline & & & $\begin{array}{l}\text { The HCP actions give priority } \\
\text { to all the stages planned. }\end{array}$ & $\begin{array}{l}\text { Little investment in group protective } \\
\text { equipment. } \\
\text { Source: Interview with the administrator } \\
\text { Context unfavorable to implementation }\end{array}$ & $\begin{array}{l}\text { Restricted to administering audiological } \\
\text { diagnosis and few hearing health } \\
\text { educational actions. } \\
\text { Source: Interview with the administrator } \\
\text { Context unfavorable to implementation }\end{array}$ \\
\hline & & \multirow[b]{2}{*}{ Formalization } & $\begin{array}{l}\text { The actions proposed in the } \\
\text { HCP and their results (annual } \\
\text { report on the administration } \\
\text { of audiological diagnosis) are } \\
\text { presented and discussed by } \\
\text { those involved. }\end{array}$ & $\begin{array}{l}\text { Takes place annually. } \\
\text { Source: Interview with the administrator } \\
\text { Context favorable to the } \\
\text { implementation }\end{array}$ & $\begin{array}{l}\text { Does not take place. } \\
\text { Source: Interview with the administrator } \\
\text { Context unfavorable to implementation }\end{array}$ \\
\hline & & & $\begin{array}{l}\text { There is a control of } \\
\text { employees with occupational } \\
\text { hearing loss onset and } \\
\text { worsening, emitting } \\
\text { notifications of accidents at } \\
\text { work }\end{array}$ & $\begin{array}{l}\text { They maintain such control and emit the } \\
\text { notification. The date of the last such } \\
\text { notification was informed. } \\
\text { Source: Interview with the administrator } \\
\text { + document analysis } \\
\text { Context favorable to the } \\
\text { implementation }\end{array}$ & $\begin{array}{l}\text { They maintain such control and emit the } \\
\text { notification. The date of the last such } \\
\text { notification was informed. } \\
\text { Source: Interview with the administrator } \\
\text { Context favorable to the } \\
\text { implementation }\end{array}$ \\
\hline & & $\begin{array}{l}\text { Planning and } \\
\text { Assessment }\end{array}$ & $\begin{array}{l}\text { Actions to monitor and assess } \\
\text { the HCP are periodically } \\
\text { conducted. }\end{array}$ & $\begin{array}{l}\text { The HCP is not assessed. } \\
\text { Source: Interview with the administrator } \\
\text { Context unfavorable to implementation }\end{array}$ & $\begin{array}{l}\text { The HCP is not assessed. } \\
\text { Source: Interview with the administrator } \\
\text { Context unfavorable to implementation }\end{array}$ \\
\hline
\end{tabular}

Source: Authors of the paper.

Caption: HCP - Hearing conservation program

Figure 4. Analysis of the structural implementation context of the hearing conservation program. 


\begin{tabular}{|c|c|c|c|c|c|}
\hline \multirow{2}{*}{$\begin{array}{l}\text { Research } \\
\text { question }\end{array}$} & \multirow{2}{*}{ Variable } & \multirow{2}{*}{ Category } & \multirow{2}{*}{ Analysis parameters } & \multicolumn{2}{|c|}{ Context evidence and classification } \\
\hline & & & & Company A & Company B \\
\hline \multirow{3}{*}{$\begin{array}{l}\text { Do the } \\
\text { strategies } \\
\text { of those } \\
\text { involved favor } \\
\text { or hinder the } \\
\text { implementation } \\
\text { of the } \\
\text { intervention? }\end{array}$} & $\begin{array}{l}\text { Support given } \\
\text { by those } \\
\text { involved in the } \\
\text { intervention }\end{array}$ & $\begin{array}{l}\text { Investments to } \\
\text { implement the } \\
\text { HCP }\end{array}$ & $\begin{array}{l}\text { Investment is made } \\
\text { on human, financial, } \\
\text { and material resources } \\
\text { for the HCP so that } \\
\text { implementing the HCP is } \\
\text { feasible. }\end{array}$ & $\begin{array}{l}\text { Available resources are proportional to } \\
\text { the necessary HCP services. } \\
\text { Source: Interview with the administrator } \\
\text { Context favorable to the } \\
\text { implementation }\end{array}$ & $\begin{array}{l}\text { No resources specifically for the HCP, } \\
\text { only for the Occupational Health sector } \\
\text { (including audiometry, hearing protection } \\
\text { devices). } \\
\text { Source: Interview with the administrator } \\
\text { Context unfavorable to implementation }\end{array}$ \\
\hline & \multirow{2}{*}{$\begin{array}{l}\text { Control in the } \\
\text { organization } \\
\text { to make the } \\
\text { intervention } \\
\text { functional }\end{array}$} & $\begin{array}{l}\text { Familiarity with } \\
\text { the HCP }\end{array}$ & $\begin{array}{l}\text { The administrators know } \\
\text { what the HCP is, as } \\
\text { well as its objectives, } \\
\text { activities, and results; } \\
\text { the main documents that } \\
\text { guide its implementation. }\end{array}$ & $\begin{array}{l}\text { Is familiar with the HCP and the } \\
\text { main documents that guide its } \\
\text { implementation. } \\
\text { Source: Interview with the administrator } \\
\text { Context favorable to the } \\
\text { implementation }\end{array}$ & $\begin{array}{l}\text { Is familiar with the HCP and the } \\
\text { main documents that guide its } \\
\text { implementation. } \\
\text { Source: Interview with the administrator } \\
\text { Context favorable to the } \\
\text { implementation }\end{array}$ \\
\hline & & $\begin{array}{l}\text { Familiarity with } \\
\text { and follow-up } \\
\text { on the financial } \\
\text { resources } \\
\text { available to the } \\
\text { HCP actions }\end{array}$ & $\begin{array}{l}\text { The HCP administrators } \\
\text { are familiar with the } \\
\text { financial values available } \\
\text { to implement and } \\
\text { develop HCP actions and } \\
\text { follow up on how these } \\
\text { resources are spent. }\end{array}$ & $\begin{array}{l}\text { Is familiar with the resources made } \\
\text { available every year to the HCP actions. } \\
\text { Source: Interview with the administrator } \\
\text { Context favorable to the } \\
\text { implementation }\end{array}$ & $\begin{array}{l}\text { Is familiar with the resources made } \\
\text { available every year to the Occupational } \\
\text { Health sector (including audiometry, } \\
\text { hearing protection devices). } \\
\text { Source: Interview with the administrator } \\
\text { Context favorable to the } \\
\text { implementation }\end{array}$ \\
\hline \multirow{2}{*}{$\begin{array}{l}\text { Are those in } \\
\text { charge of the } \\
\text { organization } \\
\text { in favor of } \\
\text { implementing } \\
\text { the } \\
\text { intervention? }\end{array}$} & \multirow{2}{*}{$\begin{array}{l}\text { Relationship } \\
\text { between the } \\
\text { underlying } \\
\text { reasons to } \\
\text { support the } \\
\text { intervention and } \\
\text { the associated } \\
\text { objectives }\end{array}$} & \multirow{2}{*}{$\begin{array}{l}\text { Considers } \\
\text { the HCP } \\
\text { implementation } \\
\text { a priority in the } \\
\text { company }\end{array}$} & $\begin{array}{c}\text { The administrators } \\
\text { consider the importance } \\
\text { of implementing an HCP } \\
\text { to prevent and/or stabilize } \\
\text { occupational hearing } \\
\text { losses }\end{array}$ & $\begin{array}{l}\text { Considers the implementation of the } \\
\text { HCP important to prevent and/or } \\
\text { stabilize occupational hearing losses. } \\
\text { Source: Interview with the administrator } \\
\text { Context favorable to the } \\
\text { implementation }\end{array}$ & $\begin{array}{l}\text { Considers the implementation of the } \\
\text { HCP important to prevent and/or } \\
\text { stabilize occupational hearing losses. } \\
\text { Source: Interview with the administrator } \\
\text { Context favorable to the } \\
\text { implementation }\end{array}$ \\
\hline & & & $\begin{array}{l}\text { They follow up on the } \\
\text { HCP annual results. }\end{array}$ & $\begin{array}{l}\text { Follows up on the results and discusses } \\
\text { them with the speech-language-hearing } \\
\text { therapist responsible for administering } \\
\text { the audiological diagnoses. } \\
\text { Source: Interview with the administrator } \\
\text { Context favorable to the } \\
\text { implementation }\end{array}$ & $\begin{array}{l}\text { Follows up on the results within the } \\
\text { PCMSO. } \\
\text { Source: Interview with the administrator } \\
\text { Context unfavorable to implementation }\end{array}$ \\
\hline
\end{tabular}

Source: Authors of the paper.

Captions: HCP - Hearing conservation program; PPE - Personal protective equipment; PCMSO - Occupational Health Medical Control Program.

Figure 5. Analysis of the policy implementation context of the hearing conservation program.

In the "Search for partnerships with other networks to develop Occupational Hearing Health actions", under "Attention given to innovation", the administrators did not know whether there was any partnership with other health networks. In its turn, "HCP actions give priority to all the planned stages", under "Centralization", was considered unfavorable, as the administrators informed that the audiological monitoring stages are given priority, whereas others, such as health education and HCP assessment, were little explored or not given any attention.

In "HCP actions are fully carried out or support from third-party company(ies) is required", under "Size", although both needed such support, only Company A's HCP administrator knew the speech-language-hearing therapist responsible for performing audiometry, who annually discussed with him its results.
Company B's administrator did not know the person responsible for performing the audiometric examinations, neither did they specifically discuss the results of the audiological monitoring. Although no contradictions were found between the administrators' statements and the evidence gathered from the other sources, Company A's administrator gave briefer and more restrict answers, while Company B's gave longer and more detailed answers about the program.

Figure 6 shows the relationship between the DI and the implementation context. It is noticed that the DI was influenced by the context, as the company that had a favorable context (Company A) achieved a higher DI than the one with an unfavorable implementation context (Company B). 


\begin{tabular}{|c|c|c|c|c|}
\hline \multirow{2}{*}{ COMPANY } & \multicolumn{2}{|c|}{$\begin{array}{c}\text { DEGREE OF } \\
\text { IMPLEMENTATION }\end{array}$} & \multicolumn{2}{c|}{ CONTEXT OF IMPLEMENTATION } \\
\cline { 2 - 6 } & $\%$ & CLASSIFICATION & CATEGORIES FAVORABLE TO IMPLEMENTATION & CLASSIFICATION \\
\hline A & $91.1 \%$ & Implemented & $\begin{array}{c}\text { Formalization of the sector responsible; Profile of the HCP } \\
\text { administrator; Attention given to innovation; Size; Centralization; } \\
\text { Formalization; HCP implementation investments; Familiarity with } \\
\text { the HCP; Familiarity with and follow-up on the financial resources } \\
\text { available to the HCP actions; Considers the HCP implementation a } \\
\text { priority in the company. }\end{array}$ & Favorable \\
\hline B & $62.7 \%$ & $\begin{array}{c}\text { Partially } \\
\text { implemented }\end{array}$ & $\begin{array}{c}\text { Formalization of the sector responsible; Profile of the HCP } \\
\text { administrator; Attention given to innovation; Formalization; } \\
\text { Familiarity with the HCP; Familiarity with and follow-up on the } \\
\text { financial resources available to the HCP actions; Considers the } \\
\text { HCP implementation a priority in the company. }\end{array}$ & Unfavorable \\
\hline
\end{tabular}

Source: Authors of the paper.

Caption: HCP - Hearing conservation program

Figure 6. Relationship between each company's degree of implementation and the context of implementation

\section{DISCUSSION}

Given the complexity and variability of the HCP actions, it is necessary to conduct assessments that consider the implementation context in which the program takes place. This type of analysis was chosen because the evaluative processes need to consider the different stages planned in the program, thus identifying and understanding the aspects that affect its results and effects 6 .

Even though the DI achieved by Company A was considered implemented, some gaps were still found in it (such as in "Assessment") - as well as in Company $B$, since neither of them invests in sturdier assessments that specifically consider the HCP actions and their variabilities.

In this regard, this seems to be a limitation of assessments that only consider the audiological results, which would possibly not be able to fully expound the effectiveness or quality of the HCP actions. The combined qualitative and quantitative assessments contribute to a more concise evaluation of the HCP quality and effectiveness ${ }^{15,16}$.

Among the dimensions assessed, "Hearing health administration" was the one with the highest score. This may be explained by the concentration of audiological monitoring actions in this dimension, as the companies often focus their attention almost entirely on these actions.

Although the audiometric examinations (which are the main tool to monitor the workers' hearing) are important hearing health indicators to the $\mathrm{HCP}$, it must be taken into account that they are only functional when they aim preventive actions and measures. Also, audiometric monitoring alone does not characterize an implemented program ${ }^{17}$.

The companies' DI results allow for an association between the characteristics of the organizations (companies) and of the administrators as elements that can either positively or negatively influence the implementation of the HCP.

It was observed that the DI was influenced by the context, as the more favorable the context (as in Company A), the higher the DI was. This contrasted with Company B's unfavorable context and lower DI. Such findings are coherent with the results of other studies $^{18,19}$, in which the implementation of other health programs was influenced by the context, with these two variables occurring in direct proportion.

The structural context proved to be less favorable to the HCP implementation than the policy one. Theoretically, an organization's structural characteristics work either antagonistically or synergically to the implementation of the program ${ }^{13}$. Even though Company A had some unfavorable categories in the structural context, its HCP was well-coordinated and planned, with satisfactory final results, based on the collected evidence.

Company A's policy context was completely favorable, unlike that of Company B. According to Company A's program administrator, they care for their workers' health and invest in it. It was also stated that they do not face many program decision-making and administration limitations, as the company's 
organizational structure enables the actions to be planned and carried out in a decentralized yet coordinated way.

According to Chiavenato ${ }^{20}$, centralization and decentralization refer to the hierarchical level in which decisions are made within an organization. Centralization means that decision-making takes place at the top of the organization, whereas in decentralization it takes place at lower levels of the organization. In the study of organizations, decentralization is more valued, as it helps decisions to be made faster by the very people who put the actions into effect; also, those who make the decisions are the best-informed ones about the program.

In the case of Company A, decentralization appears as a positive quality. Besides the decisionmaking autonomy given to the HCP administrator, such decisions are shared and coordinated with other sectors of the company, which facilitates the implementation of the program.

In Company B, on the other hand, the decisions related to Safety and Occupational Medicine are made in another sector of the company. Moreover, the administrator stated that the very actions of the program are centralized at the unit in the state's capital. Hence, other working units located inland are given little attention and investment for the program, due to the geographical distance and the delayed or inexistent communication between the units' administrators.

Therefore, centralized decision-making and actions seem to be limiting factors for HCP implementation. These findings corroborate other studies, in which decentralized occupational health actions help them to be integrated and positively contribute for results to be achieved $^{21,22}$.

Another limiting aspect of Company B listed by the administrator was the lack of agreement between the Safety and Occupational Medicine sectors, as the quantitative noise analysis data are obsolete - i.e., they had not been updated in the company for 10 years. As a consequence, those involved in the health actions refuse to continue the HCP actions because the quantification of the noise levels at the various work settings is not updated. Those responsible for the Occupational Safety sector do not give priority to updating these quantitative noise analyses - a limiting factor for the continuity of HCP actions, generating an unfavorable context for the implementation of the program.

In this scenario, these results agree with the study by Rabinowitz et al. ${ }^{16}$, whose authors found a significant association between the HCP administrators' commitment and the program's effectiveness. They further highlighted that it is important that managers give priority and be committed to the implementation of preventive actions at the workplace, so the effectiveness of the HCP is not affected.

In short, companies can implement effective programs; however, all the people involved must effectively participate in it. The health professionals and administrators must instruct and encourage the workers regarding the importance of hearing health ${ }^{23}$.

As for the follow-up of HCP costs and investments, Company A's administrator said he was familiar with and followed up such resources. This is a favorable category, as the available resources are proportional to the necessary HCP services. In contrast, Company $B$ had no specific resources for the HCP, only for the Occupational Health sector as a whole, which includes the costs with audiometry and hearing protection devices provided to the employees.

Financial resources must be directed to the HCP to ensure human resources and material. A study assessed the cost and investments related to the HCP in 14 American companies ${ }^{24}$ and concluded that the cost and adequate investment distribution are related to the positive HCP results. In other words, the greater the company's investment, the less prevalence of hearing losses among the employees.

Also, there is evidence that even after the HCP had been implemented in companies there is a substantial risk of hearing loss, as the implementation does not ensure effectiveness because the planned actions may not be fully carried out. More rigorous observation of the country's existing legislation regulating HCP actions and the more effective participation of the professionals involved in the program may reduce the noise levels at the workplace, improving the effects of the program in the long run ${ }^{25}$.

In many countries, companies must meet the requirements of governmental regulations to control noise exposure at the workplace and implement $\mathrm{HCP}^{26}$. However, despite these regulations, evidence shows that the HCP still needs to be continuously improved, and innovative strategies need to be developed, assessed, and disseminated ${ }^{27}$.

In the Brazilian context, the situation is not different. In the few studies that portray HCP assessments, the results present a distance between what is required and what takes place ${ }^{28,29}$. This reinforces the importance of all those involved in the program increasing their efforts 
to achieve better results, preventing the main problem, the occupational hearing loss.

\section{CONCLUSIONS}

Satisfactory results were verified regarding the HCP implementation in both companies assessed. "Assessment" was the dimension that obtained the lowest scores in both companies, which reinforces the need for greater investments and knowledge of health program evaluative processes in companies.

Despite each company's particularities, characteristics of the implementation context either positively or negatively influenced the functioning and results of the HCP. Context characteristics such as investments to implement the HCP, administrator's profile and centralized decision-making were listed as strongly influencing the DI.

In this scenario, there needs to be even more incentive on the part of the organizations and those involved in the program to make the implementation and functioning of the HCP feasible.

\section{REFERENCES}

1. Kirchner B, Evenson E, Dobie R, Rabionwitz P, Crawford J, Kopke $\mathrm{R}$ et al. Occupational noiseinduced hearing loss: ACOEM task force on occupational hearing loss. J. Occup. Environ. Med. 2012;54(1):106-8.

2. Ladou J, Harrison R. Current diagnosis and treatment occupational. Health and Medicine. 5th ed. McGraw Hill Education; 2014.

3. Brasil. Ministério do Trabalho e Emprego. Norma Regulamentadora №9- Programa de Prevenção de Riscos Ambientais Brasília: Diário Oficial da República Federativa do Brasil; 1994. [Internet]. [cited 2019 Ago 22]; available from: https://www. pncq.org.br/uploads/2016/NR_MTE/NR\%209\%20 -\%20PPRA.pdf.

4. Fundacentro - Fundação Jorge Duprat Figueiredo. Guia de diretrizes e parâmetros mínimos para a elaboração e a gestão do PCA; 2018. [Internet]. [cited 2019 Ago 22]; available from: http://www. fundacentro.gov.br/biblioteca/biblioteca-digital/ publicacao/detalhe/2018/9/guia-de-diretrizese-parametros-minimos-para-a-elaboracao-e-agestao-do pca.
5. Oliveira WT, Andrade WT, Teixeira CF, Lima ML. Workers' hearing before and after the Hearing Conservation Program. Rev. bras. ciênc. Saúde. 2012;16(4):517-24.

6. Champagne F, Brousselle A, Hartz Z, Contandriopoulos A, Denis J. A análise de implantação. In: Brousselle A (ed). Avaliação: conceitos e métodos. Rio de Janeiro: Fiocruz; 2011. p. 217-38.

7. Peixoto MV, Chaves SC. Analysis of the national hearing health care policy implementation in a Brazilian State. CoDAS. 2019;31(3):e20180092.

8. Yin RK. Estudo de caso. Planejamento e métodos. 3rd ed. Porto Alegre: Bookman; 2005.

9. SEBRAE-NA/ Dieese. Anuário do trabalho na micro e pequena empresa. [cited $2020 \mathrm{Abr}$ 29]. Available from: https://m.sebrae.com.br/Sebrae/ Portal\%20Sebrae/Anexos/Anuario\%20do\%20 Trabalho\%20Na\%20Micro\%20e\%20Pequena\%20 Empresa_2013.pdf.

10. Pimenta AS, Teixeira CF, Silva VM, Almeida BGP, Lima MLLT. Logical operating model of the hearing conservation program for workers. Rev. CEFAC. 2019;21(3):e1601.

11. Silva VM. Validação de indicadores para avaliação do programa de conservação auditiva [dissertação]. Recife (PE): Universidade Federal de Pernambuco; 2019.

12. Samico I, Felisberto E, Figueiró A, Frias P. Avaliação em saúde: bases conceituais e operacionais. Rio de Janeiro: Medbook; 2010.

13. Denis J, Champagne F. Análise de implantação. In: Hartz ZMA (org). Avaliação em saúde: dos modelos conceituais à prática na análise de implantação de programas. Rio de Janeiro: Fiocruz; 1997. p. 49-88.

14. Quinino LR, Barbosa CS, Samico I. Implementation analysis of the schistosomiasis control program in two municipalities in the zona da mata region of the Brazilian State of Pernambuco. Rev. Bras. Saúde Mater. Infant. 2010;10(1):119-29.

15. Gasparini MFV, Furtado JP. Programs and social services evaluation in Brazil: an analysis of practices in the current context. Serv. Soc. Soc. 2014;1(117):122-41.

16. Rabinowitz P, Cantley L, Galusha D, Trufan S, Swersey A, Dixon-Ernst et al. Assessing Hearing Conservation Program effectiveness results of a multisite assessment. J Occup Environ Med. 2018;60(1):29-35. 
17. Dantas ANM, Higuch MIG. Health professionals approach to the hearing loss prevention programme in the Manaus industrial pole. Rev. CEFAC. 2018;15(6):1418-26.

18. Oliveira L, Natal S, Camacho L. Analysis of the implementation of the Tuberculosis Control Program in Brazilian prisons. Cad. Saúde Pública. 2015;31(3):543-54.

19. Alves CK, Carvalho EF, Cesse EA, Natal S, Bezerra LC, Felisberto E. Implementation analysis of an evaluation institutionalization program in a State health department. Rev. Bras. Saude Mater. Infant. 2010;10(1):S145-S156.

20. Chiavenato I. Introdução à teoria geral da administração. 5th ed. São Paulo: Makron Books; 1997.

21. Pinafo E, Carvalho B, Nunes E. Decentralization of health management:the path traveled to date, problematic points and prospects. Ciênc. saúde colet. 2016;21(5):1511-24.

22. Balista SRR, Santiago SM, Corrêa Filho HR. Decentralization of workers' health surveillance in the city of Campinas, São Paulo State, Brazil: a process evaluation. Cad. Saúde Pública. 2011;27(4):759-68.

23. Leshchinsky A. The impact of annual audiograms on employee's habits and awareness regarding hearing protection and noise-induced hearing loss, on and off the job. Workplace Health Saf. 2018;66(4):201-6.

24. Sayler SK, Rabinowitz PM, Cantley LF, Galusha D, Neitzel RL. Costs and effectiveness of Hearing Conservation Programs at 14 US metal manufacturing facilities. Int $\mathrm{J}$ Audiol. 2017;57(1):3-11.

25. Murph P, Johnson A, Skoog B, Rosenhall U. A demonstrated positive effect of a hearing conservation program in the Swedish armed forces. Int J Audiol. 2016;55(3):168-72.

26. Suter AH. Development of standards and regulations for occupational noise. In: Crocker $\mathrm{M}$ (ed). Handbook of noise and vibration control. New York: John Wiley and Sons; 2007. p.377-82.

27. Morata T, Meinke D. Uncovering effective strategies for hearing loss prevention. Acoust Aust. 2016;44(1):67-75.

28. Gonçalves C, Iguti A. Program for hearing loss prevention in four metallurgical factories in Piracicaba, São Paulo, Brazil. Cad. Saúde Pública. 2006;22(3):609-18.
29. Cavalli R, Morata T, Marques J. Hearing loss prevention programs control of Curitiba. Rev Bras Otorrinolaringol. 2004;70(3):368-77. 